\title{
Editorial \\ Advanced Polymer and Perovskite Solar Cells
}

\author{
Jaemin Kong
}

check for

updates

Citation: Kong, J. Advanced Polymer and Perovskite Solar Cells. Energies 2022, 15, 615. https://doi.org/ 10.3390/en15020615

Received: 8 December 2021

Accepted: 11 December 2021

Published: 16 January 2022

Publisher's Note: MDPI stays neutral with regard to jurisdictional claims in published maps and institutional affiliations.

Copyright: (C) 2022 by the author. Licensee MDPI, Basel, Switzerland. This article is an open access article distributed under the terms and conditions of the Creative Commons Attribution (CC BY) license (https:// creativecommons.org/licenses/by/ $4.0 /)$.
Department of Chemical and Biomolecular Engineering, New York University, New York, NY 10003, USA; jk182@nyu.edu

This special issue was designed to draw attention to photovoltaic technology, which harnesses sunlight - the most promising renewable energy source-for our sustainable future. We have successfully selected and published six research papers [1-6] covering a wide range of photovoltaic technologies from modelling [1], molecular design and synthesis [2,3] to device fabrications [4,5] and assessment [6], and two review papers [7,8] about perovskite thin films and single crystals. Each work has their own novelty and excellency in their individual research fields. Quick summary notes for the works were presented for readers to efficiently navigate to the papers of interest, as follows:

Krzysztof Górecki et al. [1] explore the use of waste light and set up a new model of a solar cell dedicated for SPICE (Simulation Program with Integrated Circuit Emphasis). In their model, an influence of spectrum characteristics of the modeled solar cell on its photocurrent was taken into account, and the correctness of this model was verified experimentally for all the considered lighting sources, and finally the best light source for the utilization of waste light was suggested, which could be a guidance for light source selection and waste light management.

Diego Magaldi et al. [2] design and synthesize a polymerizable carbazole-based molecular glass named iDM1, comprising of a carbazole core with two 4,4'-Dimethoxydipheny lamine groups, and the molecule showed physicochemical, optical, and electrical properties that were quite similar to those of spiro-OMeTAD, which is one of the most widely used hole transport materials in perovskite solar cells. Although the power conversion efficiency (not optimized) of their perovskite solar cells with iDM1 might seem to be unsatisfactory compared to that obtained from state-of-the-art technologies of perovskite solar cells, it is worth noting that there is a potential found in in-situ polymerization of the molecules, as polymerized molecules may have different macromolecular properties that could facilitate better mechanical properties, turning films denser, which might be beneficial for device stability at the end.

Roberto Sorrentino et al. [3] propose an NDI-based ionene polymer electrolyte (NDI$\mathrm{OH})$ with an easy three-step synthesis. NDI-OH exhibits good solubility in alcohol solvents and is self-doped in a solid state, which enables the polyelectrolyte to be used for an electron transport layer. The authors show that their polyelectrolyte is quite comparable to the commercially available electron transport material, PFN, in terms of solar cell efficiency.

Joseph Asare et al. [4] demonstrate that perovskite solar cells with hybrid hole transport layers comprising two sequential layers of copper-doped nickel oxide and PEDOT:PSS exhibit higher open circuit voltage and are more stable under illumination than the solar cells with PEDOT:PSS only, which might be informative for researchers who study with PEDOT:PSS in the $\mathrm{p}-\mathrm{i}-\mathrm{n}$ structure.

Shoieb Shaik et al. [5] employ two techniques, an additive processing with Polyamidoamine (PAMAM) dendrimers to a perovskite layer and a fast lamp annealing (30 s) to rapidly form a smooth layer of PAMAM-added perovskite. Using the two techniques, the authors achieved $10 \%$ enhancement in power conversion efficiency of the processed solar cells. In particular, researchers who work on large area printings with a perovskite solution are recommended to read this paper where the 30-s fast lamp annealing replaces 1-h thermal annealing on a hot plate. 
Rodolfo López-Vicente et al. [6] assess the impact of molecular additives-5-aminovaleric acid iodide (5-AVAI), terephthalic acid (TPA), para-4-aminobenzoic acid (PABA) and 3-phosphono-propionic acid (H3PP) — on the lifetime of carbon-based mesoporous perovskite solar cells by hysteresis factors and maximum power point tracking for 1000 $\mathrm{h}$, and the authors found that extended lifetimes were attained when 5-AVAI (3\%) was used as an additive in the active layer of methyl-ammonium lead iodide solar cells. Thus, researchers interested in device stability may have a look at this work where an additive strategy was deployed, which can help design more stable perovskite layers.

Ke Wang et al. [7] review photoemission studies on the environmental stability of thermally evaporated $\mathrm{MAPbI} 3$ thin films and $\mathrm{MAPbBr}_{3}$ single crystals. In their review, the authors present the environmental stability of perovskite thin films when exposed to air, oxygen, water, and light. The surface analysis shows that perovskite thin film is not sensitive to nitrogen and oxygen, while water and light quickly destroy the perovskite structure. They also show the impact of the environmental factors (X-ray, nitrogen, oxygen, water, and light) on perovskite single crystals. Similar to the thin film, perovskite single crystals are also vulnerable to water and light, which could trigger severe damage to the structure and change the chemical composition. More detailed information can be found in [7].

Yurou Zhang et al. [8] review perovskite single crystals in terms of optoelectronic applications and strategic approaches. This review begins with a comprehensive introduction of optoelectrical properties of perovskite single crystals. Then, synthesis methods for high-quality bulk crystals and single-crystalline thin films are presented, followed by a brief review on their optoelectronic applications including solar cells, photodetectors, and X-ray detectors. A general review of the works on the perovskite single crystals and strategic suggestions for high efficiency single crystal perovskite solar cells from the reviewers are found in the last section.

Funding: This research was funded by National Research Foundation of Korea, grant number 2021R1A2C1008968.

Conflicts of Interest: The author declares no conflict of interest.

\section{References}

1. Górecki, K.; Dąbrowski, J.; Krac, E. Modeling Solar Cells Operating at Waste Light. Energies 2021, 14, 2871. [CrossRef]

2. Magaldi, D.; Ulfa, M.; Péralta, S.; Goubard, F.; Pauporté, T.; Bui, T.T. Carbazole Electroactive Amorphous Molecular Material: Molecular Design, Synthesis, Characterization and Application in Perovskite Solar Cells. Energies 2020, 13, 2897. [CrossRef]

3. Sorrentino, R.; Penconi, M.; Andicsová-Eckstein, A.; Scavia, G.; Švajdlenková, H.; Kozma, E.; Luzzati, S. An N-type Naphthalene Diimide Ionene Polymer as Cathode Interlayer for Organic Solar Cells. Energies 2021, 14, 454. [CrossRef]

4. Asare, J.; Sanni, D.M.; Agyei-Tuffour, B.; Agede, E.; Oyewole, O.K.; Yerramilli, A.S.; Doumon, N.Y. A Hybrid Hole Transport Layer for Perovskite-Based Solar Cells. Energies 2021, 14, 1949. [CrossRef]

5. Shaik, S.; Zhou, Z.; Ouyang, Z.; Han, R.; Li, D. Polymer Additive Assisted Fabrication of Compact and Ultra-Smooth Perovskite Thin Films with Fast Lamp Annealing. Energies 2021, 14, 2656. [CrossRef]

6. López-Vicente, R.; Abad, J.; Padilla, J.; Urbina, A. Assessment of Molecular Additives on the Lifetime of Carbon-Based Mesoporous Perovskite Solar Cells. Energies 2021, 14, 1947. [CrossRef]

7. Wang, K.; Ecker, B.; Gao, Y. Photoemission Studies on the Environmental Stability of Thermal Evaporated MAPbI3 Thin Films and MAPbBr3 Single Crystals. Energies 2021, 14, 2005. [CrossRef]

8. Zhang, Y.; Lyu, M.; Qiu, T.; Han, E.; Kim, I.K.; Jung, M.C.; Ng, Y.H.; Yun, J.-H.; Wang, L. Halide perovskite single crystals: Optoelectronic applications and strategical approaches. Energies 2020, 13, 4250. [CrossRef] 